\title{
Earth at Rest
}

\section{Aesthetic Experience and Students' Grounding in Science Education}

\author{
Edvin Østergaard ${ }^{1}$ (D)
}

Published online: 4 July 2017

(C) The Author(s) 2017. This article is an open access publication

\begin{abstract}
Focus of this article is the current situation characterized by students' de-rootedness and possible measures to improve the situation within the frame of education for sustainable development. My main line of argument is that science teachers can practice teaching in such a way that students are brought in deeper contact to the environment. I discuss efforts to promote aesthetic experience in science class and in science teacher education. Within a wide range of definitions, my main understanding of aesthetic experience is that of pre-conceptual experience, relational to the environment and incorporated in students' embodied knowledge. I ground the idea of Earth at rest in Husserl's phenomenological philosophy and Heidegger's notion of science' deprivation of the world. A critique of the ontological reversal leads to an ontological re-reversal that implies giving lifeworld experience back its value and rooting scientific concepts in students' everyday lives. Six aspects of facilitating grounding in sustainability-oriented science teaching and teacher education are highlighted and discussed: students' everyday knowledge and experience, aesthetic experience and grounding, fostering aesthetic sensibility, cross-curricular integration with art, ontological and epistemological aspects, and belongingness and (re-)connection to Earth. I conclude that both science students and student-teachers need to practice their sense of caring and belonging, as well as refining their sensibility towards the world. With an intension of educating for a sustainable development, there is an urgent need for a critical discussion in science education when it comes to engaging learners for a sustainable future.
\end{abstract}

\section{Introduction}

How can science teaching support students' connectedness to the world? What are potential inclusions of aesthetic experience in science education to strengthen students' grounding?

Edvin Østergaard

edvin.ostergaard@nmbu.no

1 Department of Mathematical Sciences and Technology, Section for Learning and Teacher Education, Norwegian University of Life Sciences, P.O.Box 5003, N-1432 Ås, Norway 
These questions are based on some assumptions: First, that disconnectedness is a problem for students (caused at least partly by science), and second, that science education and science teacher education have a responsibility for supporting students' need to find firm ground. These assumptions I will critically examine, and they will eventually form the basis for a discussion of possible measures towards a grounded, sustainable science education.

The teacher education at the Norwegian University of Life Sciences has Education for Sustainable Development (ESD) as its central aim. ESD is a reaction against ways of (science) teaching that have promoted non-sustainable, societal development. Education is acknowledged as an essential field for achieving a sustainable development (Sterling 2001). ESD (and related initiatives like sustainability education and sustainable pedagogy) raises some crucial questions: How can science education actively contribute to the severe environmental, technological and scientific challenges of our time? How should science teacher education meet these challenges? Our science-teachers-to-become will meet students in class who can be encouraged to contribute to a sustainable future in society. During their training, student-teachers should be given possibilities to practice skills to promote sustainable development. Critical thinking about the sources of unsustainable actions and positive examples of sustainable ways to go about with resources is important, but not sufficient. Other competencies regarded as vital for a sustainable renewal are, among other, collaboration, communication and social skills, creativity, system thinking and problem solving (Voogt and Roblin 2012). As I argue in this article, there is also the need to practice skills as that of belonging, caring and (re-)connecting to the environment.

The field of education is recognized as "an indispensable element for achieving sustainable development" (United Nations 2002). Hence, the UN proclaimed the period from 2005 to 2014 to be the International Decade of Education for Sustainable Development. Despite this fact, very little has been achieved during the last 10 years (Jegstad and Sinnes 2015). An education for sustainability, Vilches and Gil-Pérez (2013) claim, remains practically absent nowadays in many high schools. Jickling and Wals (2008) assert that the agenda of sustainable development within environmental education has suffered under instrumental and deterministic tendencies in teaching and learning. Both environmental education and alternative (e.g. ecojustice) ways of engaging people in questions about how human beings and other species live on this Earth "run the risk of being marginalized or excluded" (p. 18). Recent studies report significant educational reforms during the last decades aiming to improve student performance on national and international educational assessments, among them the far most influential being OECDs Programme for International Student Assessments (PISA). In a comparative study of ESD and PISA, Sinnes and Eriksen (2015) show that although the UN acknowledged the importance of sustainability for education, "other measures than those adopted under this programme have had greater success in influencing and shaping educational reforms". The consequence of a policy that has as its main goal to score higher on international student assessments (like PISA) might even be counterproductive when it comes to implementing ESD (p. 9). In order to climb on the PISA rank, measures characterized by test-driven teaching and learning have been taken, which probably promote rather than prevent students' alienation. Aims to strengthen the effectiveness of ESD seem closely related to measures to strengthen students' grounding.

In this article, I discuss the current situation characterized by students' de-rootedness and possible measures that science teaching can take to improve the situation. Clearing the philosophical foundation for such an improvement is one of my main intentions. Which significance should students' world-connectedness and being-at-home in the world have in sustainability education? I focus on measures to strengthen aesthetic experiences as part of 
science learning, as well as on science teachers bridging the gap between students' lifeworld and science subjects. Heidegger (1962) claimed that our fundamental way of being-in-theworld is a caring way. Should not students' sense of caring and belonging become a learning goal that is added to science curriculum? My main line of argument is guided by the question of how teachers can practice science teaching in such a way that the students are brought in deeper contact with the environment.

\section{Science education: students' alienation and de-rootedness}

Critique of the effectiveness of science education and science students' achievements is not new. For example, Flannery (1992) lamented the knowledge level among biology students and, in general, the level of scientific literacy among the public. In this article, however, the focus is on students' weakened relation to the environment in the light of sustainability education. I start by surveying research on students' alienation and de-rootedness and on the fast-growing research area of ESD and environmental education.

\subsection{Being alienated and de-rooted}

In his analysis of current science education, Roth (2015) described a situation characterized by students' experience of being de-rooted and alienated. Students' alienation occurs in several forms: First, students experience a gap between science-based knowledge presented in class and their own everyday knowledge. What they are taught in science class is seldom (if ever) put in relation to their personal lives (Jung 2012). Second, students' own experiences and personal knowledge tend to be devaluated in relation to scientific knowledge. Current science education causes uprooted children, Roth (2015) argued, because it confronts children's familiarity with the world with science-based concepts that they find foreign and incomprehensible. Third, a fundamental feeling of alienation affects students' attitude towards science as well (Danielsson et al. 2016). The primary emphasis of science teaching on conceptual cognition will, Dahlin (2001) maintained, contribute to students' alienation from nature, as well as from science. Science itself has an alienating effect, Jung (2012) claimed, as loss of safety and feeling-at-home in and with nature.

There are several studies that describe students' detachment and alienation in relation to nature and environment. In an ethnographic study among science student-teachers, Beach (1999) argued that students' experiences can be understood as alienation and reification. As analogue to how humans in a capitalistic production system become alienated in their work due to a lack of influence and participation, students become alienated in science laboratories because their operation is institutionally determined. Students are not given the opportunity to discover something new or question the existing theory; rather, they are expected to confirm the already established knowledge. Danielsson et al. (2016) drew a somewhat similar conclusion, though within a different theoretical discourse compared to Beach's study. One hundred and twenty pre-school and primary school student-teachers were asked about their science learning experiences from school. The analysis showed that many of the students experienced "existential outsideness, a self-conscious and reflective un-involvement, including a feeling of alienation from the place and the people who inhabit it" (p. 1120). When reflecting on the classroom as a place, the students almost without exception expressed strong negative emotions, experiences of outsideness and alienation. Bonnett (2006) argued that alienation 
from nature and from oneself are highly interrelated and key to our ability to despoil the environment. The author raised the question of the nature of Western rationality and its adequacy to understand and address environmental issues.

Teaching strategies that are heavily reliant on explanation and demonstration, as often found in science class, might contribute to "thingifying" views of science and of the world itself, views that often generate "a sense of alienation, if not fear, towards nature" (ColucciGray and Camino 2016, p. 34). When universities and schools teach single disciplines, a fragmented view of reality is promoted that could contribute to "a sense of detachment and alienation among ourselves and from the natural system" (Colucci-Gray et al. 2013, p. 144). Without making explicit connections to science or science education, Nisbet et al. (2009) maintained that disconnection from the natural world is an underlying course for current environmental problems. The authors developed and discussed Nature Relatedness (NR), a scale for assessing affective, cognitive, and experiential aspects of individuals' connection to nature. Their findings showed a gap between many people's feelings and attitudes about environmental problems and their own actions. Using the NR scale, Gray and Sosu (2015) analysed empirical data from more than 800 college students expressing their childhood experiences of nature and their sense of nature relatedness. Preliminary results showed that there is a significant difference in sense of being connected to nature among groups of first year's students; compared to other students, physical science students have a significantly lesser sense of nature connectedness. Further, childhood experiences in nature appear to have a significant influence on current students' sense of mental well-being. The authors concluded that early experience in nature might actually help to provide some resilience within young people with regard to sense of mental well-being. In a related study on the human-nature relationship, Schroeder (2007) explored people's experiences of environments and places they encounter in their lives. The results showed that a deepened sense of the human-nature relationship and the qualities of places "may give rise to a feeling of moral responsibility towards nature" (p. 293). A sensation of connectedness seems to be linked ethically to how we go about with nature.

Only a few of these studies actually connect science and science education to alienation. Thus, it is unsubtle to claim that science education is the only reason behind students' feeling of alienation and loss of firm ground. We cannot assume that school science alone produces de-rooted students; the students might already enter science classroom with a feeling of derootedness. However, there seems to be sufficient evidence to claim a connection between modern science' (or even scientism's) worldview and a growing feeling of de-rootedness among students. It is, moreover, difficult to find research that indicates a promotion of belonging in nature caused by science education.

Terms like "rooted", "grounded", "related to" or "connected with" have their own meanings, but they also have something in common. The way I use the notions in this context all refer to having a sensation of being-here-and-now rather than feeling estranged from place and time. Ground does not only refer to planet Earth but also to the world as familiarity, lived experience and meaningful interrelations. Rootedness has multiple meanings, for instance of being connected to a geographical place and to a culture, a language, a lifeworld. Our familiar world, our everyday dealings, Heidegger (1962) claimed, "has the character of closeness" (p. 135; emphasis in the original). Heidegger did not use "close" in a physical meaning, but rather with an existential intent, close as familiar with and intimate acquainted with. Despite of an explicit clarification of terms, the personal experience and cultural meaning of them varies. A sense of nature relatedness (Nisbet et al. 2009) might be experienced differently by a 
Norwegian student and a German student, by a kindergarten child and a 20-year-old one, or by a biologist and an artist. In addition, notions like nature, environment, lifeworld and everyday life - dimensions into which one is more or less rooted or grounded - are ambiguous concepts that are difficult to be given precise definitions. When discussing measures to promote grounding, it is necessary to have an idea of the diversity of nature concepts and nature's values. This problem I discuss more in Section 5.

Drawing on the French philosopher Simone Weil and her notion of rooting (enracinement), Roth (2015) argued that de-rootedness (déracinement) in school must be faced with "forms of education that counter alienation by grounding themselves in children's familiarity with the world and in the expansion of this familiarity through immediate experience" (p. 471). With reference to the works of the German science educator Martin Wagenschein, Jung (2012) argued that teachers have a heavy responsibility when it comes to connecting school science with the students' primary world. In physics, for example, the teacher should...

...not only lead the child from his primary world which is colourful, resounding, emotional, "buzzing", to the world of science, but in such a way that the child/student becomes aware of the constructive character of science; in such a way that he/she stays rooted in this primary world... (ibid., p. 1075; my emphasis)

Wagenschein (1990) argued that a major problem in science teaching is the order of sequences: Too often teachers plan deductively from the end. They start with basic concepts and mathematical structures, aiming at making these understandable to the students and thereby using laboratory experiments as mere illustrations. Wagenschein argued that teachers should seek opportunities for students to develop experience in direct contact with their environment. Does current education for sustainable development provide such opportunities?

\subsection{Education for sustainability}

There is a growing research activity related to ESD and sustainability education. As stated by Sinnes and Eriksen (2015), little has been done with regard to transforming UN's measures into educational policy and practice. Despite of the importance of chemistry in ESD, both experienced chemistry teachers and student-teachers struggle to apply ESD ideas and green chemistry in their teaching (Jegstad and Sinnes 2015). The notion of green chemistry is "the creation, development and application of products and chemical processes in order to reduce or eliminate the use and generation of substances which are harmful to human health and the environment" (Sjöström et al. 2016, p. 322). As these authors argued, there is a need to supplement green chemistry with socio-critical perspectives in order to educate professionals who are able to engage more profoundly in democratic decision-making on sustainability issues. The idea that chemistry should be engaged with environmental issues is supported by Pienta (2014) who advocated a chemistry teaching that draws on students' own experiences from everyday life. Birdsall (2013) has developed a framework for integrating science and education for sustainability in New Zeeland. The empirical study showed that after a period of integrated teaching, the students demonstrated a deeper understanding of sustainability, as well as an emerging ability to take action on an issue in a number of ways. Increased engagement in sustainability issues also led to an increased interest in science among the students.

Issues of sustainability have become increasingly relevant also in higher education. Here is, Burns (2015) argued, a need to address complex cultural and ecological problems. Among the 
key goals of sustainability pedagogy, one is to increase "learners' understanding of and connection with the ecological and cultural place and community in which they live" (p. 263). The author also emphasized learners as change-makers and learning grounded in a specific place. Sterling (2014) pointed to congruence as one of the major criteria for successful ESD programs i.e. programs "sufficiently grounded in real world issues and concerns, reflecting the systemic nature of the real world and the current threats and opportunities this presents" (p. 97). The current environmental situation requires an education for change that responds to contemporary conditions of complexity, uncertainty, stresses and unsustainability (Sterling 2010). The notion of transdisciplinarity represents a higher-order learning towards increased ecological consciousness and an integrative practice "affording a deeply relational sense of what it is to be human at this most challenging of times" (p. 217). This view is shared by Thomas (2009) and Adomßent (2013), the latter arguing that transdisciplinarity has been established on the university level as a comparatively new participative form of scientific practice and culture concerning involvement with sustainability. Similarly, Colucci-Gray et al. (2013) claimed that transdisciplinarity is essential for the articulation of and dialogue between different forms of knowledge in academia.

ESD's emphasis on political actions and changed values, attitudes and new ways of thinking - and especially critical thinking as advocated by Sterling 2014, Thomas (2009), Upadhyay (2005), Jickling and Wals (2008) and others - raises an urgent question: If the main problem is not the lack of knowledge, of new sets of values or of appropriate ways of thinking, but rather decreased sensibility towards our coalescing with nature, how do we revitalize such a competency? Colucci-Gray and Camino (2016) noted that embodied experiences and practical work are vital elements of sustainability education. Kagan (2012) argued that the true sustainability problem is the atomization of knowledge, because it represents a severe hindrance for cultivating our sensibility towards the complexity of the world. The challenge is essentially to reconnect ourselves "to our embodied knowledge and to the many subconscious sources of knowledge that lie within ourselves" (p. 28). The challenge is to bring together scientific and personal knowledge: "I do not lack intellectual insight about my dependence on pollinating insects, micro plankton or ground vegetation for my survival - but I miss bodily experience to anchor this insight into" (Granström and Elmerstad 2016, p. 36; my translation). Hindering (further) numbness and cultivating sensibility that supports our ability to sense the environment aesthetically seem to be crucial measures.

Everyday knowledge is one fundamental dimension of embodied knowledge. As Jung (2012) argued, students' de-rootedness might occur when (rooted) lifeworld knowledge is regarded as a set of incomplete conceptions that should be replaced with correct science. One may even find a certain hidden agenda when it comes to replacing "children's original, spontaneously formed 'schemata' with those which science has established as more correct and 'true"” (Dahlin 2001, p. 469). For instance, when "only $45 \%$ of the population know that the earth revolves around the sun annually" (Flannery 1992 , p. 1), the knowledge of more than half of the asked group of persons is regarded as wrong knowledge. Do perhaps such misconceptions in reality indicate a kind of knowledge that lies deep hidden in our personal selves? The scientifically correct explanation of Earth moving around the sun might overshadow a more self-evident and intuitive feeling of being one with the resting Earth. Heidegger claimed that intuitive, personal knowledge, which science and science education are inclined to pass off as "subjective", very well might be real sources for perceiving reality. The existential aspects of grounding I will go deeper into in the next section. 


\section{Science philosophical foundation: seeking firm ground}

In his discussion of intuitive everyday conceptions of Earth as firm ground, Roth (2015) noted: "Of course, scientists themselves continue to marvel at a beautiful sunrise or sunset" (p. 475). The fact that our language enables us intelligibly to refer to a sunrise or sunset reveals a viewer experiencing the world from a grounded first-person's view. Both Edmund Husserl and Martin Heidegger discussed the complex relation between ground at rest and Earth as a physical object (among other objects).

\subsection{Husserl and Earth that does not move}

In 1934, Edmund Husserl wrote an essay on the spatiality of nature and man's ground connectivity. The essay gives a valuable insight into Husserl's later works on the theory of origin (Urspungslehre) and corporality (Körperlichkeit). Here, Husserl elaborated in detail on the differences between man's relation to Earth in a physical, geometrical sense and in an existential meaning, between Earth as a moving body, an object among other objects, and Earth as firm ground, as human's primordial home. In its original meaning, Husserl claimed, the Earth does not move, "she rests" (Husserl 1940, p. 313; my translation). ${ }^{1}$ Earth is "true ground" and "ground body" (Bodenkörper) (p. 317) with which our human bodies are connected. Husserl elaborated on Earth as foundation for our relational bodily experiences:

First, it should be stated, that it does not make sense to talk of an empty universe beforehand as we do in the already endless "astronomic" world; as a space in which Earth is, just like [other] bodies are, and which surrounds Earth. We have a surrounding space as a system of locations, that is a system of possible endings of bodily movements. However, in this [system] all earthly bodies have a particular "position", but not Earth itself. (p. 313; my translation)

By claiming that Earth rests, it was of course not Husserl's intention to question the Copernican worldview. Rather, he contrasted the scientifically describable Earth with man's intimate connectedness with the Ark Earth. The notion of ground at rest is in contrast to the natural scientific, self-evident description of Earth as one out of an endless number of heavenly bodies. Science has conveyed to us, Husserl claimed, an undeniable conception of Earth as a body "on which we coincidentally crawl about" (p. 320; my translation). We take as selfevident,

... that Earth is just one of the random bodies in space, one amongst others. After Copernicus it is almost ridiculous to claim that Earth, "just because we coincidentally live on her", is the center of the universe, even favored because of her "rest", in relation to which all moving [things] move. It seems as if we (...) through the previous have blown a breach in the natural-scientific naïvity. (p. 321; my translation) ${ }^{2}$

Husserl's attempt to "blown a breach in the natural-scientific naïvity" is but a premonition of his critique of western science in the 1936 published The Crisis of the European Sciences

\footnotetext{
${ }^{1}$ Husserl wrote on the envelop of the manuscript: "Earth, the originary Ark, does not move" (Husserl 1940, p. 307), in German original: "Die Ur-Arche Erde bewegt sich nicht"; translated in Roth (2015, p. 470) as "The originary ark, earth, does not move". By adding "Ur-Arche" to Earth, it seems that Husserl wanted to emphasize even stronger the primordial character of Earth as a vessel containing all living things.

2 I translate "bloss weil wir zufällig auf ihr wohnen" with "just because we coincidentally live on her", that is referring to Earth as female noun, to emphasize Earth's Mother character. For the same reason, I translate "sie [die Erde] ruht" (Husserl 1940, p. 313) with "she [Earth] rests".
} 
and Transcendental Phenomenology (Husserl 1970). Here, Husserl argued that the natural sciences have lost contact with the lifeworld and that its value has to be restored. Husserl used the term "lifeworld" in slightly different meanings, but somewhat simplified, it can be defined as the world in which we live. Lifeworld is the world that we self-evidently presuppose in our everyday lives; the pre-conceptual, pre-scientific world of experience that we are familiar with and that we do not question (Zahavi 2003). In Crisis, Husserl referred to lifeworld as "the given practical world of perceptual experience from which all scientific activity takes its point of departure" (Hardy 2013, p. 44). In lifeworld, "there is no pure point of view and there is no view from nowhere, there is only an embodied point of view" (Zahavi 2003, p. 98). It is against this background that Husserl claimed that every world experience is made possible by the person's embodiment.

Husserl claimed that we can only comprehend moving and resting bodies when these are seen in relation to Earth as a resting ground. "Rest is something decisive and absolute, as is movement: that is to say on the first step of the constitution of Earth as body" (Husserl 1940, p. 321; my translation). We sense rest and motion related to "an experienced 'ground body' at rest, with which my bodily corpus is unified" (p. 311; my translation). As a prerequisite for experiencing motion and rest, there is an experience of a ground (Roth 2015). Accordingly, the feeling of groundedness is a sensation of one's body and Earth's body being united.

To experience Earth as moving ground was the intention behind Jean Bernard Léon Foucault's famous pendulum experiment in 1851. Foucault invited the public to come and watch the moving pendulum - or more precisely the movement of the pendulum's plane of oscillation. By switching perspective, from seeing the plane of oscillation as moving to regarding it at rest, they themselves could experience to be in motion, as part of a rotating Earth. Foucault's experiment is the definitive expression of the transition from a geocentric to a heliocentric worldview. The transition forever changed humankind's self-awareness in relation to the Earth as it implies a loss of stability and solid ground to stand on. Today — when nothing is stagnant and everything moves in relation to everything else - every child knows that the Earth rotates; we certainly do not need a Foucaultian pendulum to prove that. I have argued that the common interpretation of Foucault's pendulum experiment that Earth beneath our feet is rotating primarily makes sense in a geometrical space (Østergaard 2015). A turn to the existential space, the space in which Earth rests, implies a new interpretation of Foucault's pendulum in the span between movement and rest. Whereas geometrical space is infinite and without a centre, I myself form the centre in the existential space. Husserl talks here of our bodies as "central bodies" (Zentralkörper) (Husserl 1940, p. 311). It is from this centre that I can experience the moving pendulum as a "being-in-motion rather than a swinging object" (Østergaard 2015, p. 192).

I now turn to the similarities between Husserl's critique of science' reduction of Earth as a body "on which we coincidentally crawl about" and Heidegger's notion of being and his warning against an Entweltlichung, a deprivation of the primary world.

\subsection{Heidegger and the deprivation of the world}

Our sense of place is inseparably connected to the experience of being-in-the-world. "Place" has several meanings, as the geographical position found on a map, as the imprint of moments in one's biography, or as the place you carry with you, wherever you go. In the novel Sweet Tooth, Ian McEwan tells the story of a woman in the post-war England who has moved to London from the countryside. Here, she meets three young women with whom she shares an 
apartment. The three women all come from Stoke-upon-Avon and are described as working class members with rather simple backgrounds. They have, however, a strong wish to leave all that behind: "They each told me in their different defiant ways that they were never going back. And they were not speaking of Stoke in purely geographical terms." (McEwan 2013, p. 75) For these women, their hometown is a geographical place, but it is first of all a mental dimension (connected to their proletarian background). Leaving Stoke is motivated by leaving behind their past and starting anew in a promising city. This double meaning of space is described in both Husserl's phenomenological investigation of Earth and in Heidegger's existential-phenomenological space analysis.

In Being and Time, Heidegger (1962) investigated our existence as being-in-the - world. What does "being" mean? And, do we at all have an understanding of the significance of the question? For Heidegger, an entity or a being is "anything that in any sense is" (Gorner 2007, p. 15; emphasis in the original). The most basic structure of existence is being-in-the-world (p. 4). The term "being-there" (Dasein) refers to a specific mode of "Being of humans, emphasizing its individuality and its role in the disclosure of Being" (Moran 2000, p. 238). The term "world" signifies "a context, an environment, a set of references and assignments within which any meaning is located" (p. 233). ${ }^{3}$ Being is the primordial foundation that our intellect takes for granted and rests upon. Our basic contact with things in the environment does not come about through conceptualizations. Rather, we encounter things in terms of their use and availability to us for certain purposeful tasks. Accordingly, things in our environment "present themselves with this kind of available being" (p. 233). Heidegger referred to such things as "ready-to-hand" (zuhanden) and of their mode of being as "readiness-to-hand" (Zuhandensein) (Gorner 2007, p. 38). A pure examining of things as objects "standing on their own", irrespective of their use, is a theoretical way of viewing things and equals a science approach. Things viewed in this mode are "present-at-hand" (vorhandene) (Moran 2000, p. 233). The preposition "in" in being-in-the-world does not signify a relationship of two spatially separated things to each another, but rather the purposeful, availability aspect of things due to our utilizing acquaintance with the world (Thomson 2004). The fundamental structure of being-in-the-world is a "being with things and with others in such a way that its whole existence is structured by care (Sorge)" (Moran 2000, p. 238). Dasein's specific character of being-in-the-world is not a private one, but a shared one; it is being-in-the-world-with-others.

In his space analysis in Being and Time, Heidegger (1962, pp. 135-148) investigated the ontological problem of space. He made a distinction between geometrical space and existential space; the first being describable by laws of physics, the latter the pre-scientific, pre-conscious and self-evident space of existence. Existential space refers to our primordial world: "The 'environment' does not arrange itself in a space which has been given in advance; but its specific worldhood, in its significance, Articulates the context of involvements which belongs to some current totality of circumspectively allotted places" (p. 138). The specific character of worldhood is a context involving objects of utility ready-to-hand. On the basis of Heidegger giving primacy to our being and rootedness in the world, we cannot define closeness and rootedness in mere spatial terms. Closeness is not to be regarded within a three-dimensional coordinate system without a centre; it is a human sensation of being connected to and embedded in.

\footnotetext{
${ }^{3}$ Heidegger distinguished between world (without inverted commas) as "that which makes it possible for entities to show themselves or be encountered" and "world" that referred to "innerworldly entities" (Gorner 2007, p. 53). Heidegger did not use Husserl's term lifeworld.
} 
When analysing space, Heidegger did not explicitly distinguish between the moving and the resting Earth. However, he referred to the sun as a moving entity in relation to Earth, as "something which is ready-to-hand":

Thus the sun, whose light and warmth are in everyday use, has its own places - sunrise, midday, sunset, midnight; these are discovered in circumspection and treated distinctively in terms of changes in the usability of what the sun bestows. Here we have something which is ready-to-hand with uniform constancy, although it keeps changing. (p. 137)

When Heidegger referred to the sun's "own places", it might be interpreted as the sun's positions in the sky. However, it more specifically indicates the sun's positions in man's lived environment, the experience of sunrise and sunset, of midday and midnight. The sun represents a constant in human's life, and "although it keeps changing", it is not primarily a blazing object in the sky. Imprints of the sun we can find for example in the positioning of churches and graves (p. 137). This signifies the presence of the sun "in everyday use" in the world.

Heidegger's analysis of the world's spatiality leads to the conclusion that the geometrical space presupposes the existential space and that it is not the other way around. Being is a precondition for conceiving the dimensions of the metrical space. Our existence is not something that is filled into an empty, three-dimensional space. Rather, we are always already in the world. When the world is investigated scientifically "by just looking at it", our environment is "neutralized to pure dimensions" (p. 147):

The 'world', as a totality of equipment ready-to-hand, becomes spatialized [verräumlicht] to a context of extended Things which are just present-at-hand and no more. The homogeneous space of Nature shows itself only when the entities we encounter are discovered in such a way that the worldly character of the ready-to-hand gets specifically deprived of its worldhood". (p. 147; italics in original)

This argument I interpret as a warning against scientism's reduction of the originary world in which we live. Moreover, it is also a description of how to reach the metrical, homogenous space. Metrical space can only be accessed "if the environment is deprived of its worldhood" because "spatiality is not discoverable at all except on the basis of the world" (p. 148). However, if one is primarily oriented towards the metrical space, "the primordial spatiality of Being-in is concealed" (p. 141). Heidegger's indication that a one-sided emphasis on the geometrical space might lead to an Entweltlichung of human's original world is highly relevant for current debates in science education.

\subsection{The ontological reversal and its implications for teaching science}

Both Husserl and Heidegger discussed the problem of the overarching authority of abstract scientific (mathematical) knowledge over lived, experienced forms of knowledge. In Crisis, Husserl (1970) argued that the scientific culture of Europe had uncritically accepted the Cartesian dualism and its consequent objectivistic and naturalistic view of knowledge and its acquisition. The natural scientific attitude has been passed down through the modern scientific tradition (Hardy 2013) and is today, we might add, prominently present in science classrooms. Husserl was not opposed to natural science per se; indeed, he argued that natural sciences and our knowledge of the laws of nature should be firmly grounded (Gallagher 2012). His critique was directed against scientism, the objectivistic view that everything can be fully 
explained by natural science. The only way "to heal the disastrous rupture between the world of science and the world of everyday life is by criticizing this reigning objectivism" (Zahavi 2003, p. 126). Natural scientific thought has invaded our intuitive notion of Earth as point of rest. Words like sunset and sunrise, common everyday wisdom, remind us of the fact that our language is full of immediate and intuitive utterances rooted more in everyday experience than in science-based understanding. What we need is a natural science in closer contact with our self-evident lifeworld.

In his discussion of Husserl's Crisis, Harvey (1989) defined the ontological reversal as an ontological position where abstract models from science are considered as more real than the everyday reality itself. This position is signified by "a tendency in naturalistic thought to replace and explain (away) the thing of appearances (that is, the thing of the life-world) by the mathematically substructed, purely material thing in itself of natural science" (p. 74). According to the natural scientific attitude, the world is in principle given as mathematically determinable and after the world is determined, "nothing is left over" (p. 65). The scientific objectivities...

\footnotetext{
... seem to take on a life on their own because of the multiple strata of cognitive achievements - that is, the many-layered, sense-bestowing acts of consciousness - are no longer experienced; and the scientific objectivities now seem to stand disconnected over and above the fluctuating appearances of daily life while explaining these appearances. (ibid., p. 63; italics in original)
}

Ontologically speaking, what is real has been reversed. Now, if one is primarily oriented towards objectively measured things, one is, Heidegger claimed, inclined to pass off estimates and interpretations of the world as subjective. However, this subjectivity "has nothing to do with 'subjective' arbitrariness or subjectivistic 'ways of talking'". On the contrary, the socalled subjectivity "perhaps uncovers the 'Reality' of the world at its most Real" (Heidegger 1962, p. 141).

The ontological reversion has some severe consequences for teaching science subjects. As long as science presents the world from a position "over and above the fluctuating appearances of daily life" (Harvey 1989, p. 63), students are not given the opportunity to realize how scientific knowledge is related to everyday experiences and that it in fact always presupposes the lifeworld as its ontological foundation (Dahlin 2001). As long as abstract, scientific models are taken as the real causes behind everyday experiences, models that by their nature are to be conceptually understood and explained, teachers tend to put less emphasis on students' own perception and experience (Dahlin et al. 2009). One should discuss, though, whether starting in everyday life per se leads to more grounded learning. Tal and Dierking (2014) stated that researchers who are engaged in learning that occurs outside of schools are convinced that a wide range of environments promote various types of engagement and learning. This positive effect might, however, just as well be caused by increased variation of learning spaces. Calabrese Barton and Tan (2009) argued that there is empirical evidence that pedagogical approaches grounded in students' own cultural backgrounds and everyday knowledge can improve learning. They focus on hybrid spaces where everyday resources are integrated with disciplinary science learning. In these hybrid spaces, "science is no longer a separate world as students learned to display competent and meaningful scientific literacy in applying scientific knowledge to their local communities and their daily living" (p. 70). The authors refer to a biology lesson, where the students made a class salad from various plant parts, sharing their favourite home salad recipe with the class. This is but one example of viable pedagogical initiatives to include everyday issues in science class. 
A critique of the ontological reversal, expressed by science educators like Wagenschein, might form the very basis for a return to the rootedness in the world. An implication of this critique is to begin teaching from the start, ideally starting in open-minded sense experiences, in children's everyday lives, personal and intuitive knowledge (Wagenschein 1990). From this, the teacher designs a learning path towards abstract knowledge and models. Wagenschein (1968) proposed a genetic-inductive approach to teaching and learning science where the teaching sequence is reversed. Ullrich (2008) reported challenges with inductive science teaching from a classroom study of physics students in a Waldorf school. The study explicitly focused on the transition from students' lifeworld-related understanding of phenomena to mathematical abstraction in models and formulas. The author observed that the teacher's instruction speed increased the closer they came to abstractions and conceptualizations. Further, the study showed that only few students managed to follow the path from the perception of a phenomenon to conceptual understanding. Similar results are found also in research on science teacher education. In an empirical study on phenomenon-based sound exercises, we found that pre-service science student-teachers felt more at home in the deductive approach than in the genetic-inductive approach, despite the fact that the exercises clearly encouraged them to use the latter (Østergaard and Dahlin 2009). In order to understand genetic-inductive science teaching better, more practice-based research is needed.

In mainstream science education, teachers tend to give secondary significance to explorations of phenomena, whereas scientific concepts and models used in order to explain the phenomena are of primary importance. Such an attitude Dahlin (2001) referred to as the primacy of conceptual cognition. Here, phenomena are used as examples of theoretical knowledge, whereas sensing is reduced to a pedagogical tool for quasi-openly looking for what has already been defined. A primacy of perception implies a reversed position where theoretical knowledge provides examples of how sensed phenomena can be described, explained and understood. Obviously, an ontological re-reversal implies giving lifeworld experience and sense perception back their values. It is a problem for both students and student-teachers if the borders between the real and representations of the real are fuzzy or even non-existent. It is a problem for students if their teachers mistake the derived for the original. Students can grasp concepts of lifeworld phenomena in a grounded way only if they understand what the representations are supposed to represent (Dahlin et al. 2015).

\section{Aesthetic/s and aesthetic experience in science education}

In this section, I will elaborate on the definitions of aesthetic, aesthetics and aesthetic experience with focus on their relevance to science education. I distil approaches to science teaching that are relevant for discussing how sustainable science teaching might promote groundedness.

\subsection{On aesthetic/s and aesthetic experience}

Etymological speaking, the noun "aesthetics" relates to perception via the senses, ultimately derived from the Greek verbs aisthesthai, "perceive, watch, sense", and aisthanesthai, "notice, discern, observe". The adjective aisthetikos, first used in Kant's writings as "aesthetic" (German "ästhetisch"), is in its original sense translated as "perceptual" (Ayto 1990). With its etymological origin in Greek aisthetike episteme, the noun aesthetics can be translated as "knowledge of and 
acquaintance with the sensuous impressions and the sensations (whose harmonious unity was held to be the fundamental law of beauty)" (Herman 1992; my translation). The philosophical understanding of aesthetics is strongly influenced by Baumgarten's work Aesthetica from 1750. Currently, aesthetics as a branch of philosophy is understood as the theory of the beautiful or beauty (Herman 1992). The implicit connecting of aesthetics and beauty is probably one reason why aesthetics often is assigned the arts, especially the fine arts (Wickman 2006). As currently used, aesthetic is, in one way or the other, synonymous with beautiful or similar characteristics like tasteful, graceful, elegant, exquisite, attractive, pleasing or lovely (Lindberg 2004).

In Art as Experience, John Dewey (2005) elaborated on the multiple relationships between aesthetics, experience and humans' interaction with art, nature and the environment. Dewey focused on the act of aesthetic experience beyond the conventional emphasis on the art object itself. Experience as "the result, the sign, and the reward of that interaction of organism and environment which, when it is carried to the full, is a transformation of interaction into participation and communication" (p. 22). True aesthetic experience unifies person and environment: The listener and the listened are one. As part of experiencing, aesthetic is related to sensing as we cultivate "a careful and exact attention to all the qualities inherent in sense experience" (Dahlin 2001, p. 454). In the aesthetic experience, there is no distinction of self and object, and as such, aesthetic experience is one of being-in-the-world-with-others.

Closely related to Dewey's ideas is the notion of relational aesthetics with its focus on the variety of relations and interactions between humans and lifeworld phenomena (Omholt 2013). This approach is relevant for the discussion of students' grounding and sustainability education as it emphasizes our participation in the world, rather than our standing above it. Relational aesthetics means enhanced sensuous experience of the environment by relating to it. How can, in an educational setting, the specific qualities of aesthetic experience as relating to and being in the world be fostered? As I further discuss in Section 5, we here also find a potential for cross-curriculum efforts between art teachers and science teachers.

\subsection{Aesthetic/s and aesthetic experience in science teaching}

How are aesthetic experience and aesthetics interpreted and used in science education? Which significance do aesthetic experience and aesthetics have in current science education debates? A literature survey shows a variety of understandings. Here, I discuss them in the following five groups: sense experience, beauty, art, aesthetic understanding and wholeness.

Incorporating sense experiences in science teaching is a major concern in phenomenonbased science education (Østergaard et al. 2008). An intention of phenomenology in science learning is to restore the value of sensing and experiencing; aesthetics "cultivates a careful and exact attention to all the qualities inherent in sense experience" (Dahlin 2001, p. 454). Phenomenon-based learning is related to inquiry-based learning approaches as both emphasize students' own process as well as the process of scientific examination. However, compared to inquiry-based approaches, phenomenon-based teaching emphasizes more the explorative phase, including sensing and associating as intrinsic parts. Sensing is pre-conceptual because it is, at least to begin with, free of (cognitive) words and terms. Having a sense experience is not the same as putting words to the experience. ${ }^{4}$ The manifold of lifeworld sense experiences

\footnotetext{
${ }^{4}$ The prefix in pre-conceptual and pre-logical (Root-Bernstein 2002) creates an expectation that experience (and logic) can be turned into words. This assumption is highly questionable. There is human experience beyond words. Are non-conceptual and non-logical designations that are more accurate?
} 
constitutes a reservoir from which learning paths towards scientific conception can be walked. The notion of doing phenomenology in science class, that is to employ phenomenology as a science Didaktik, is quite different from Husserl's original project (Gallagher 2012). The phenomenological intention in science learning is related to similar measures to enhance children's observation skills (Jakobson and Wickman 2008) and generally to include perception in education (Pugh and Girod 2007).

Several science education researchers have connected aesthetic experience to beauty, in one way or the other. Flannery (1992) used aesthetics in the meaning of beauty - of a scientific thought, in the experience of doing science, as well as in the scientist's appreciation of nature. One argument for including aesthetic dimensions in science courses is an enhanced perception of nature. For Girod (2007), finding beauty in science is essentially a matter of identifying the elements of a "scientific aesthetic space" (p. 41). The author distinguished between four dimensions: beauty in the representation of scientific ideas, descriptions of beauty in science, as that which inspires awe and wonder, beauty in conversations related to cosmology or God's creation, and beauty in the nature of scientists' experiences themselves. In their review of creativity in science education, Kind and Kind (2007) stated that similarities between art and science are found when considering science as an aesthetic and creative activity. They did not explain precisely what makes an activity in science aesthetic, but they showed that the use of drama and poetry in school science might be ways that students gain an aesthetic experience. Girod et al. (2003) define aesthetics as beauty inherent in scientific ideas and in scientists' own description of their field of activity. They argued that one goal of teaching science is to make students awake to the world and more capable of appreciating beauty of nature, as well as "to move students out into the world, beyond the walls of the classroom to enriched experiences and interactions with the world" (p. 585). With the intention to show that aesthetic experience is an inseparable part of learning science, Wickman (2006) looked at the inner beauty of science, as well as its intellectual and spiritual requirements. He also investigated how students talk aesthetically in science class. Apparently, this implies a primary access to aesthetic experience as to how it is verbalized.

Multiple relations between aesthetics, aesthetic experience and art in science teaching can be found. Kearns (2015) described wonder as an integral part of aesthetic, ethical and pedagogical experiences, connecting aesthetics to the appreciation of art and works of art, such as music, poetry, architecture, sculpture, painting and photography. In an empirical study, Jakobson and Wickman (2008) discussed the reciprocity between teaching science and teaching art. In addition to maintaining that art exercises enhance children's observation skills, they found children's aesthetic experiences to be richer. They showed that aesthetics relate not only to art but also "to science and the entire experience of learning and meaning-making" (p. 155). The intention of art-based environmental education is to strengthen students' sensibility towards the environment though art practices (Boeckel 2013). With reference to Dewey's understanding of aesthetic experience, Pugh and Girod (2007) argued that aesthetic experience has a transformative potential because it enables students to see aspects of the world in a new way. In a comparative study, Root-Bernstein (2001) defined musical and scientific abilities as correlative talents i.e. skills in several different areas "that can be integrated to yield surprising and effective results" (p. 64). He mentioned aesthetic sensibility as one such skill often associated with music that has been an important correlative talent for many scientists. Finally, Song (2010) discussed how art can heighten both children's cognition and their engagement with the natural world. The author advocated an integration of artists' work into school curriculum (without explicitly mentioning science). An aesthetic sensitivity is a kind of 
sensitivity that is promoted when engaging with works of art. Aesthetic experience enables children to bond with the natural world, and they learn "to love nature rather than just be afraid that it is going to be destroyed" (p. 106).

Several researchers have referred to aesthetic understanding as a tool for better learning science. Girod et al. (2003) for instance claimed that "science learning is something to be swept-up in, yielded to, and experienced" within aesthetic understanding, as opposed to conceptual understanding where science is something to be "analysed, stood back from, and acquired" (pp. 575-576). The aim of aesthetic understanding, they argued, is to develop coherence of parts, pieces, ideas and concepts. With the intention of exploring the effectiveness of integrating aesthetic understanding in reflective inquiry activities, Lin et al. (2011) established guidelines for teaching for aesthetic understanding. Among these, we find promoting students' imaginative and creative skills as well as "creating content to recapture or reanimate existing content into artful and compelling ideas" (p. 1200). Aesthetic understanding also means to inspire students' appreciation for the beauty of science. Aesthetics is part of the scientific process, Root-Bernstein (2002) argued, as pre-logical sensations and intuitive feeling of understanding. A scientist has the ability to translate informal, intuitive insights into formal results of logic. Aesthetic cognition signifies a "sense that one knows something before one has the ability to express what one knows in words or equations" (p. 62). This kind of cognition takes place at the creative, intuitive and emotional stage proceeding the cognitive. Common for these research approaches are intentions to study the interfaces between aesthetics, aesthetic experience and cognition.

Some research works connect aesthetics to wholeness and the feeling of connectivity to the world as a larger whole. In a study of outdoor education, Quay (2013) contrasted a rational (cognitive) with an aesthetic (sensory) teaching approach. Grounded in Dewey and Heidegger, but without explicitly referring to science education, the author argued that aesthetic experience is a way of being-in-the-world. Outdoor education is not merely teaching moved out of the classroom; for teachers, it is essentially a way of practicing aesthetic experience: "Such shaping of aesthetic experience, of ways of being [with self, others and nature], of occupations, is the art of teaching" (p. 153). A similar line of thought was promoted by Kagan (2011), who discussed aesthetics as the sensibility to patterns which connect. Instead of defining the concept of aesthetics, he characterized the skill of being aesthetical as being "able to recognize characteristics similar to their own in other systems they might encounter" (p. 27). He referred to Bateson (1979) who defined aesthetic (as adjective) as "responsive to the pattern which connects" (p. 8; emphasis in the original). Thus, being aesthetical always encompasses oneself as part of the greater pattern. ${ }^{5}$ Finally, the idea of aesthetic experience and wholeness resonates with the notions of "aesthetic sensibility" (Root-Bernstein 2001) and "aesthetic sensitivity" (Song 2010).

In conclusion, this literature survey shows a diversity of ways with which art, aesthetics and aesthetic experience are merged in science learning. There seems to be a gap between approaches to aesthetics as features of external object - be that of nature objects, of ideas or of processes - and those that regard aesthetic experience as the competency that connects viewer and the viewed (as advocated by Dewey). Only a few of the works focused explicitly on aesthetic experience and rooting or grounding: Song (2010) stressed artwork and bonding

\footnotetext{
${ }^{5}$ In Bateson's works, it remains undetermined, however, exactly how one is connected to the connecting pattern and how the specific skill of being responsive to the pattern can be trained. In Mind and Nature, Bateson (1979, p. 211) admitted that "aesthetics" (and "consciousness") are untouched questions in the book.
} 
with the natural world, and Girod et al. (2003) emphasized students' interactions with the world and aesthetic understanding as a holistic enterprise. Finally, some researchers explicitly drew connections between aesthetics, science education and sustainability education: Kagan (2011) and transdisciplinary sensibility, Omholt (2013) and relational aesthetics, and Boeckel (2013) and art-based environmental education. Manni (2015) argued that aesthetic experience can support students' meaning making of environmental and sustainability issues and that it requires openness to personal emotions and values as a starting point.

\section{Promoting students' grounding in science teaching}

What are potential relations between science learning, sustainability and students' grounding? In which ways can aesthetic experience contribute to strengthen students' grounding? Here, I discuss six issues related to possibilities and constrains when facilitating aesthetic-sensitive, sustainability-oriented science teaching and teacher education.

\subsection{Students' everyday knowledge and experience}

Science teachers can learn to (re-)value students' everyday knowledge and to make use of their personal experience, Wagenschein $(1968,1990)$ claimed, by teaching science genetically. ${ }^{6}$ This requires that teachers explicitly draw lines between experience-based knowledge on the one hand and preconceptions and wrong knowledge on the other. There is, as Jung (2012), Danielsson et al. (2016) and others have argued, a link between disregarding students' everyday knowledge and their feeling of alienation. In order to merge scientific knowledge and students' experiences, science teachers in one way or the other have to consider their students as first-persons. In Husserl's phenomenology, emphasizing the first-person perspective implies that lifeworld phenomena are always appearances of something for someone; there is always "an embodied point of view" (Zahavi 2003, p. 98). Instead of rejecting students' personal perspective as incorrect knowledge scientifically speaking, their knowledge can be an entrance into science teaching guided by the (often very general) learning goals in the curriculum.

There are, however, several challenges when linking science learning to issues in students' everyday life. If students' lived experience should be part of science learning, as advocated for example by Upadhyay (2005), one must ask: Whose experience is chosen to form a starting point? Calabrese Barton and Tan (2009) showed that it can make a difference in learning when pedagogical approaches are grounded in students' cultural backgrounds and everyday knowledge. They concretised this in hybrid spaces, which are learning situations where science is fused with lifeworld issues. Another way of approaching the challenge of utilizing students' lived experiences is to support linguistically and culturally diverse learners to learn science. This can happen "if the teacher encourages and nurtures students to share their experiences as funds of knowledge in science classrooms" (Upadhyay 2005, p. 106). Each teacher has to decide the usability of everyday life experiences in class, based on a broad understanding of

\footnotetext{
${ }^{6}$ With a reference to Wagenschein, Roth $(2015$, p. 471) describes the genetic approach to teaching, "which emphasizes the slowness of the process by means of which students expand what is familiar to them to eventually include the sciences and, thereby, regain the home that they have lost."
} 
the nature of lived experience and what kind of experiences are suitable and for whom - the individual student or the whole class.

As shown by Danielsson et al. (2016) in teacher education, preservice science teachers almost without exception associated classroom with strong negative emotions, including experiences of outsideness and alienation. One way to counter such associations is to introduce a positive thinking that can serve the purpose of helping student-teachers become aware of potential connections to science in their previous positive experiences. By using students' personal knowledge connected to former experiences, teacher educators could "accentuate the science aspects, with the goal of extending students' feeling of insideness related to the place to a feeling of insideness in science" (p. 1132). By doing so, teacher educators utilize students' former personal experiences actively. As long as aspects of their everyday lifeworld experience are considered to be "less real (or even unreal)" (Dahlin 2001, p. 457), science students may sustain a feeling of detachment. Acknowledging student-teachers' personal, lived experiences could form the bases for themselves, in their future profession, to appreciate and use students' experiences in science class.

\subsection{Aesthetic experience and grounding}

When sense competencies are devaluated compared to cognition and abstraction skills in science class, the very foundation upon which scientific cognition is based erodes. Sensuous experiences are presuppositions for our everyday lives (Zahavi 2003); scientific cognition presupposes a world of experience that we are familiar with. Aesthetic experience understood as pre-conceptual sense experiences is primarily achieved by participation in the world, not by verbal reflection. The richness of everyday experiences constitutes a reservoir upon which scientific conception is built (Wagenschein 1968).

In phenomenologically oriented science teaching, the intention of sense-perceptual activities is to balance the predominant skills of abstract conceptualization (Dahlin et al. 2015). When bridging lifeworld and the world of science, the students move in both directions: Scientific (abstract) concepts are grounded in (pre-conceptual) lifeworld experiences and gained conceptual knowledge refines students' ability of rich sense experiences (Østergaard and Dahlin 2009). One possible reason why sense experience is not emphasized in current science teaching is that sensing and perception are taken for granted and rarely taught systematically (as in contrast to schooling of observation skills in art education and listening skills in music education). Another reason probably relates to time constraints and teachers' perceived priority of content over process. Are students encouraged to trust their own senses and their abilities to improve them? And if not, how can this trust be established? In phenomenon-based teaching and learning, restoring the value of aesthetic experience also implies restoring the value of lifeworld phenomena. As already described, an ontological rereversal implies returning to lifeworld phenomena as primordial entities, as more than examples of scientific theory.

Embodied knowledge is personal knowledge grounded in the world as existential foundation. Phenomenologically speaking, we are one with Earth as a ground body (Husserl 1949, p. 317) and our knowledge presupposes groundedness. Embodied knowledge is connected to being "within which any meaning is located" (Heidegger 1962, p. 233), and it constitutes bodily accumulations of our participation in the world. When embodied knowledge is the sum of world experiences, one might ask whether the notion of feeling-at-home in the world is of another kind than the experiences of being socially connected via technology-based forms of 
communication. Kagan (2012) argues that technology-mediated experiences might generally contribute to numbed experiences of both nature and culture. Do new technology and social media improve or impair students' capability to connect profoundly to the environment? Does social technology bring one closer to life or is it rather the illusion of life that is mediated? Is not the kind of closeness that technology offers a pretended closeness, "intimate, satisfying and adapted to one's needs, but at the same time controllable and completely free of risk" (Granström and Elmerstad 2016, p. 46; my translation)? The current predominance of technology-based social communication necessitates a broad debate on students' world embodiment and its inclusion in science learning.

An aesthetic experience has, as advocated by Kagan (2011), the ability to bond the experiencer with the world as greater pattern. The significance of sense experience in phenomenon-based science education is expressed by employing the senses openly. An experience is specifically aesthetic when it opens up a world through pure sensing; it allows the world to disclose itself. Scientific conceptualization presupposes such an experience when translated into a formal language. Without bonding and embodied knowledge, there is a risk that the world is "neutralized to pure dimensions" (Heidegger 1962, p. 147) and thus the primary character of being is further concealed.

\subsection{Fostering aesthetic sensibility}

All beings in the world express themselves, in all kinds of ways. Nature speaks in hundred languages, but we have, as Dahlin (2001, p. 454) has pessimistically proclaimed, become deaf of 99 of them. If being in the world means being through our senses and bodies, then there is a need for an awareness of how we are in the world with our bodily senses and how the world discloses itself to us through the senses. To access this expressiveness, we need to cultivate our aesthetic sensibility (Dahlin et al. 2015). What does aesthetic sensibility mean? ${ }^{7}$ RootBernstein (2001) characterized aesthetic sensibility as a skill often associated with music and the art. Song (2010) considered aesthetic sensitivity as what is promoted when engaging with works of art. In phenomenology, sensibility is connected to refined aesthetic perception and to the quest to cultivate "sensibility towards things" (Dewey 2005, p. 51). Aesthetic sensibility is not only the skill of being sensitive towards the beauty in nature, but it also implies an intentional readiness to encounter the world as it appears in our eyes, our ears and our bodies. If one reduced aesthetics to a question of nature's beauty or science's beautiful ideas or idealizations, the whole aesthetic part would be subordinated as means for either artistic experience or scientific cognition.

Fostering this specific kind of sensibility in science class also requires an ability to reflect critically on how scientific explanations serve as a kind of filter that tends to "black out" aesthetic aspects of the examined phenomenon. By doing so, the richness of the phenomenon is reduced to what is scientifically explicable. The phenomenon is robbed of its expressiveness; what remains for the students is partly understandable, in worst cases something completely incomprehensible (Østergaard 2015). As science teacher educators, we should be concerned with the question how, instead of blunting our students' aesthetic sensibility, we might cultivate and acuminate it. Nature speaks, and so does experience. Training sensitiveness in

\footnotetext{
${ }^{7}$ I use the terms sensibility, sensitivity and sensitiveness synonymously: as awareness and mental responsiveness.
} 
the encounter with nature and phenomena and being sensitive towards one's own rich experiences are two sides of the same coin.

Aesthetic sensibility is a sort of competency that is promoted when engaging with works of art (Song 2010). However, it is not self-evident that art engagement per se will lead to increased sensibility towards nature. If students' increased aesthetic awareness should be transformed into a sensibility towards the environment and oneself as embedded in the greater whole, a true integration of art in science class is required.

\subsection{Cross-curricular integration with art}

The genetic approach to teaching science, Roth (2015) argued, "lends itself to cross-curricular integration" (p. 491). As I have advocated in this article, there is a close link between aesthetic experience and art. Even though aesthetic sensibility is not exclusively tied to art or artistic experience, art can support the specific competency of sensibility we are dealing with here. In a sustainability perspective, we should discuss whether the one-subject hegemony in teaching promotes or detains the feeling of alienation and de-rootedness. Are not the current environmental challenges of an extremely complex nature? And should not the efforts to solve them be of a cross-disciplinary kind? When universities and schools promote a fragmented view of reality (Colucci-Gray et al. 2013), it is justified to ask how cross-curricular efforts might resist this tendency. Adomßent (2013) argued that the value of transdisciplinarity in current educational system is to be found in knowledge communication rather than in knowledge production. Such communication is found between art teachers and science teachers (Jakobson and Wickman 2008) but needs to be further developed.

The basic idea of art-based environmental education is to revitalize an environmental awareness through art practices (Boeckel 2013). Aesthetic experience, Kagan (2011) argued, fosters a sensibility that highlights "the interpenetration of nature and culture" (p. 267). These perspectives point at the specific cross-curricular potential between artists, art teachers and scientists and science teachers. Flannery (1992) claimed that emphasizing the aesthetic dimensions of science might link the science disciplines closer to one another because several aesthetic qualities are important in several fields. Teaching science in collaboration with artpositioning students "in the path of potentially unfolding aesthetic experiences" (Girod et al. 2003, p. 579) - presupposes a learning environment that allows for synaesthetic experiences and creative participation. A true pedagogical integration of science and art, conventionally regarded as being far apart, requires a critical reflection on the hierarchy of modes of knowing and how modern society has "numbed the intuitive and metaphorical sources for a knowledge of the many connections between different aspects of our reality" (Kagan 2012, p. 12).

Art-inspired activities require time for open inquiry. In most cases, however, there is little time for openness in science class. As returning to the primacy of sense experiences is a prerequisite for teaching and learning science genetically, open inquiry activities are more than mere introductions to conceptual learning. Students should be given the opportunity to practice the skills of phenomenon unfolding and world disclosure. When the world discloses itself, when phenomena present themselves ready-to-hand (Heidegger 1962), it is due to the person's readiness to encounter the phenomena on their own terms. ${ }^{8}$ When, however, too little room is

\footnotetext{
${ }^{8}$ Cf. Heidegger (1962): "When we let entities within-the-world be encountered in the way which is constitutive for Being-in-the-world, we 'give them space'. This 'giving space', which we also call 'making room' for them, consists in freeing the ready-to-hand for its spatiality" (p. 146; emphasis in the original).
} 
granted for the pre-conceptual phase, when teachers regard open inquiry as a waste of time, the phenomena become mere objects present-at-hand. Thus, creating learning spaces where a lifeworld phenomenon can present itself - in its own richness, in its own languages - is an educational challenge. By allowing for open inquiry in a learning environment not familiar to most of the students, they can encounter the environment in a new way. The skill of being open-minded is emphasized as a core competency in sustainability education (for example Sterling 2014). Training the skills of open inquiry presupposes an attitude of world-openness, a mindset often found in artists' work.

There are several surpluses when it comes to merging art and science teaching; here, I will merely point at four of them. First, schooling of sense experience is a self-evident element of art education (drawing in art class, ear training in music class), and science teachers would benefit from this expertise in a collaboration. Second, practicing open inquiry can provide students with the opportunity to come in a more direct contact with nature and environment. It might help them throw off "the covers that hide expressiveness of experienced things" (Dewey 2005, p. 108). Third, art can enable students to cultivate skills of creativity, which is essential in sustainability education (Jegstad and Sinnes 2015; Sterling 2014). Creativity in this sense embraces both the creativity of mind, by creating new scenarios for wanted future situations, and also the creativity of form. Fourth, there is a need to balance the predominance of intellectual and conceptual efforts, which characterizes the majority of current understandings in sustainability education, with a more beauty-oriented, emotional and sensuous learning approach. Maybe Jakobson and Wickman (2008) were right when they suggested that we should stop asking whether art is promoting science learning and instead investigate the different ways that art activities can contribute to students' making sense of science. Still, there are some prejudices to be overcome and educational experiences to be made in order to merge art meaningfully into science teaching.

\subsection{Ontological and epistemological aspects}

Heidegger's existentialism and Husserl's phenomenological critique are not subjects taught directly in school science. However, when it comes to reflecting on profound values inherent in science teaching, it is important — especially in teacher education - to highlight the nature of science and the foundation of scientific inquiry. "As science cannot answer this question about itself the education of scientists does not equip them to respond”, Shaw (2013, p. 547) noted. In science teacher education, such issues seem self-evident as preparation for student-teachers future teaching practice. When learning science content and methods, "students will learn something about science - its nature, its history, how it differs from non-scientific endeavours, and its interactions with society and culture" (Matthews 2009, p. 697). Science curricula do open up for the inclusion of historical and philosophical issues, in science teacher education as well as in science class. The problem is that these opportunities too often remain unused. Critical reflections on the ontological reversal and its pedagogical application as teaching from the end could prepare the ground for student-teachers' learning and self-reflection. Grounding science teaching in science philosophy (and history) supports the debate within ESD on how modern science has led to unsustainability and how values of sustainability pedagogies must be put into practice.

In his famous crab lecture, Gregory Bateson (1979) asked art students, what are the patterns which connect? He was glad to teach students "who were not scientists and the bias of whose minds was even antiscientific" (p. 8). Now, at our teacher education program, the situation is different: Science student-teachers attending the program are all trained in at least one science subject. The 
typical student-teacher has obtained a master's degree in biology or chemistry and wants to become a biology or chemistry teacher. Even though hard to define, they have biases - worldviews, scientific values and attitudes - that influence how they look at nature and eventually how they view teaching about nature and natural science. When teachers teach science, they employ, consciously or not, a philosophy of science (Shaw 2013). In an empirical study among upper secondary school students, Hansson and Lindahl (2010) showed that students who have a worldview different from the one they associate with science tend to exclude themselves from science and technology programmes in school. It is necessary in science classes to problematize science-based worldviews, they argued, "for example through showing examples of science researchers with different kinds of worldviews" (p. 911). It is of even greater importance, I would add, that student-teachers learn to reflect on their own biases that they bring into science class. Reflection foci are for example the intrinsic value of nature, the nature of scientific knowledge and implicit values of their own education in biology or chemistry.

The debate concerning sustainability education affects several ontological questions: What is nature? And which value does nature have? In discussing a 12-point framework concerning measures to promote students understanding of the relation between science and sustainability in education, Birdsall (2013) did not explicitly address values of nature. The framework encompassed "Appreciation of the nature of science" (p. 459) without mentioning the nature of nature or aesthetic aspects of nature, as emphasized by authors like Bonnett (2006) and Dahlin et al. (2015). Hovardas (2013) discussed ecocentrism and nature's intrinsic value, that is the value that nature possesses independently of human valuers. He criticized ecocentrism as it might support and retain a dualistic distinction between society and nature. He proposed an alternative conceptualization, informed by the approach in environmental education and ecology education, and both educators and students can be supported by this conceptualization "to unravel the heterogeneity of positions among social actors engaged in protected area management” (p. 1478). Sjöström et al. (2016) defined and established a philosophical foundation for eco-reflexive science education. Elements here are for example holistic thinking as an educational ideal. The training of such skills seems crucial for both science students, student-teachers and teacher educators.

The epistemological question of how to gain valid knowledge is (or should be) an implicit aspect of a science teacher education. Colucci-Gray and Camino (2016) advocated a pluralist epistemology, ranging from science studies to anthropology, law, psychology and neurosciences, "all seeking to understand the changing conceptions of science and technology in face of ecological and social change" (p. 27). Here, we are reminded of the fact that the very epistemological basis of modern science and technology is in motion. While recognizing the interrelatedness of social and environmental issues, a foundation for sustainability education must imply a "fundamental change in how humans relate to each other and to nature” (Jordan and Kristjánsson 2016, p. 1). Bonnett (2006) raised the question of the nature of Western rationality and its adequacy to understand and address environmental issues. In the centre of a vital sustainability consciousness "lies the notion of a right relationship with nature which both conditions our attitudes towards the environment and our sense of our own identity" (p. 9). Epistemologies do not only affect interpretations of nature but in the end also our identity as citizens of the Earth.

\subsection{Belongingness and (re-)connection to Earth}

The problem of students being alienated from nature, a feeling generated among others by science, touches upon the issue of students' sense of belonging and caring. Phenomenon-based teaching stresses the importance of training sensuous skills to cultivate closeness as the 
sensation of being connected to or embedded in nature. Phenomenology's objective is "to elucidate and clarify our experience of knowledge and learning about nature" (Dahlin 2001, p. 470; emphasis in the original), using the whole spectrum of personal competencies, from thinking and reasoning to feeling and imagining. Related to the major skills in education for sustainable development — critical thinking, system thinking, problem solving, communication, creativity and so on - we should define more explicitly the skills of caring, belonging and grounding. Teachers can be encouraged, Goodnough (2010) has argued, to be more attuned to their beliefs, values and possible selves. This type of knowledge relates to how individuals view themselves as future teachers - the ideal selves they would like to become. We have to ask ourselves whether being-in-the-world as caring and belonging are obvious experiences for our children. If not, how could these competencies be addressed in science class or in crosscurricular cooperation with other school subjects?

Belonging and grounding are issues not often found in current debate on ESD, with its primary emphasis on political, social and cultural aspects. A sustainable relationship with nature, Jordan and Kristjánsson (2016) have argued, "involves not just the recognition that we are part of a larger ecosystem, but also a deeper, more complex understanding that nature is inextricably linked to society as a whole, as well as to individuals" (p. 14). This is in accordance with Schroeder's (2007) analysis regarding the sense of human-nature relationship that may give rise to a feeling of moral responsibility towards nature. Measures to support students' world belonging cannot be grounded in a scientific position above the fluctuating appearances of daily life (Harvey 1989), but rather in a science rooted in being. When discussing the existential dimension of being-in-the-world, Heidegger (1962) pointed at care as the fundamental component. Caring as active world involvement cannot be taught solely theoretically; it has to be practiced - both in science class and in science teacher education. Could such a practice prevent the tendency of deprivation of the world (Heidegger 1962) and objectification and thingifying (Colucci-Gray and Camino 2016) that affect views of science, of the world itself, as well as ourselves as human beings?

\section{Conclusions}

I have argued that students' detachment from nature and environment does constitute a problem and that possible measures towards strengthening their groundedness are an integral part of sustainability education. Teaching for aesthetic sensibility, belonging and caring ought to be obvious parts of sustainability pedagogies. Gross (2002, p. 413) claims that "sense is essentially achieved by sensibility", thus connecting the dimensions of sensing, sense making and aesthetic awareness. Sensing and sense have several bearings:

But sense, as meaning so directly embodied in experience as to be its own illuminated meaning, is the only signification that expresses the function of sense organs when they are carried to full realization. The senses are the organs through which the live creature participates directly in the on-goings of the world about him. In this participation the varied wonder and splendor of this world are made actual for him in the qualities he experiences". (Dewey 2005, p. 22)

Here, Dewey brought together essential aspects of personal, embodied knowledge; as sense organs, that is our ears, eyes and hands; as participation in the world's on-goings, that is our active involvement in the world; as a way to open up for the wonder and splendour of this world; and as meaning, that is meaningful experiences that make sense. These aspects are all connected to an 
existential feeling of groundedness. However, it would be incorrect to claim causality between the aspects, for example that cultivating the sense of observation (hearing or seeing) in science class per se leads to students' feeling of meaningfulness. The specific relation between the aspects is one to be researched in detail. Carried into the field of education, it is the task of teachers to bring sense "to full realization" when the goal is the students' own "illuminated meaning". It is the teachers' task to make the world's "wonder and splendour" transparent and meaningful for their students. In Dewey, we hear the echoes of Heidegger's notion of the world as familiarity and meaningful interactions. Thus, bringing sense experience to realization is a way to foster students' own meaning-making.

In science education, there is a need for a critical discussion when it comes to engaging learners for a sustainable future. Do students need more knowledge, provided from yet another research report? Or do they rather need to practice the skills of getting more intensively involved in the world and refining their sensibility towards the world's on-goings? If the latter is true, as I have advocated in this article, we need an explicit focus on teaching towards the development of these skills in both science education and teacher education. This entails stimulating the "sensitivity to the qualities of things" (Dewey 2005, p. 51) and developing profound trust in students' and student-teachers' own sense experiences. As "the embodied awareness of place is an expression of affinity praxis" (Larsen and Johnson 2012, p. 635), so is embodiment as being-in-the-world a field of competency exercises. It does matter for our students whether they are encouraged to develop their personal relation to Earth or they are caught in yet another purely intellectual debate about environmental issues. What you care for, you tend to protect. If Earth is nothing but a body "on which we coincidentally crawl about" (Husserl), how can our students be expected to feel belonging, to show care?

By working my way through this field of investigation, several questions have turned up, questions which I have barely touched upon. It seems obvious that in the light of radical new societal conditions, we should discuss contemporary challenges of promoting rooting and preventing de-rooting. Which influences do new technology, media and computer tools have on students' ability to connect to the Earth as ground body (Husserl) and to prevent further deprivation (Heidegger)? Which images of nature does present-day schooling inspire in young people? It is necessary to conduct further empirical studies concerning students' feeling of alienation in order to discuss more specifically the role of science education. Moreover, how can art and artistic practices in science education contribute to dealing with environmental and technological challenges of our time? And how can science teachers foster the skills of caring and belonging and at the same time teach facts-oriented science? These questions all affect the challenges of improving students' grounding.

For many science education researchers, the concept of aesthetics is associated with the beauty of the world and the wonders of science as idea, process or outcome. I doubt that beautiful ideas or aesthetic features of scientists' appreciation of nature's beauty alone will encourage students to contribute to a sustainable future. Valuing these aspects might very well contribute to students' increased consciousness about science' unfolding of nature's "wonder and splendour" (Dewey). It might also broaden students' notion of science and scientific inquiry. The question is, however, whether such arguments will convince young people of the urgency of dealing with our time's severe environmental, technological and social challenges. When our fundamental way of being-in-the-world is a caring one, then science teachers and teacher educators will have to facilitate the refinement of such a skill.

Acknowledgements I would like to thank the four anonymous reviewers of this paper for their valuable comments. I am also grateful for constructive suggestions and benevolent inspirations from colleagues at the Department of Philosophy, Humboldt-Universität, Berlin during my sabbatical 2016-2017. 


\section{Compliance with Ethical Standards}

Conflict of Interest The author declares no conflict of interest.

Open Access This article is distributed under the terms of the Creative Commons Attribution 4.0 International License (http://creativecommons.org/licenses/by/4.0/), which permits unrestricted use, distribution, and reproduction in any medium, provided you give appropriate credit to the original author(s) and the source, provide a link to the Creative Commons license, and indicate if changes were made.

\section{References}

Adomßent, M. (2013). Exploring universities' transformative potential for sustainability-bound learning in changing landscapes of knowledge communication. Journal of Cleaner Production, 49, 11-24.

Ayto, J. (1990). Bloomsbury dictionary of word origins. London: Bloomsbury.

Bateson, G. (1979). Mind and nature. A necessary Unity. London: Wildwood House.

Beach, D. (1999). Alienation and fetisch in science education. Scandinavian Journal of Educational Research, 43(2), 157-172.

Birdsall, S. (2013). Reconstructing the relationship between science and education for sustainability: a proposed framework for learning. International Journal of Environmental and Science Education, 8, 451-478.

Boeckel, J. v. (2013). At the Heart of Art and Earth. An Exploration of Practices in Arts-Based Environmental Education. Helsinki: Aalto University publication series, Doctoral Dissertations 73/2013.

Bonnett, M. (2006). Education for sustainability as a frame of mind. Environmental Education Research, 12(34), 265-276.

Burns, H. L. (2015). Transformative sustainability pedagogy: learning from ecological systems and indigenous wisdom. Journal of Transformative Education, 13(3), 259-276.

Calabrese Barton, A., \& Tan, E. (2009). Funds of knowledge and discourses and hybrid space. Journal of Research in Science Teaching, 46, 50-73.

Colucci-Gray, L., \& Camino, E. (2016). Looking back and moving sideways: following the Gandhian approach as the underlying thread for a sustainable science and education. Visions for Sustainability, 6, 23-44.

Colucci-Gray, L., Perazzone, A., Dodman, M., \& Camino, E. (2013). Science education for sustainability, epistemological reflections and educational practices: from natural sciences to trans-disciplinarity. Cultural Studies of Science Education, 8, 127-183.

Dahlin, B. (2001). The primacy of cognition — or of perception? A phenomenological critique of the theoretical bases of science education. Science \& Education, 10, 453-475.

Dahlin, B., Østergaard, E., \& Hugo, A. (2009). An argument for reversing the bases of science education - a phenomenological alternative to cognitionism. NorDiNa, 5(2), 201-215.

Dahlin, B., Hugo, A., \& Østergaard, E. (2015). The nature of nature: ontologies in learning science. In P. Kemp \& S. Frøland (Eds.), Nature in education, Vol. 3 of "philosophy of education" (pp. 66-80). Zürich: LIT Verlag.

Danielsson, A. T., Andersson, K., Gullberg, A., Hussénius, A., \& Scantlebury, K. (2016). "In biology class we would just sit indoors...": experiences of insideness and outsideness in the places student teachers' associate with science. Cultural Studies of Science Education, 11(4), 1115-1134.

Dewey, J. (2005). Art as experience. London: Penguin Books.

Flannery, M. (1992). Using science's aesthetic dimension in teaching science. Journal of Aesthetic Education, 26(1), 1-15.

Gallagher, S. (2012). On the possibility of naturalizing phenomenology. In D. Zahavi (Ed.), The Oxford handbook of contemporary phenomenology (pp. 70-93). Oxford: Oxford University Press.

Girod, M. (2007). A conceptual overview of the role of beauty and aesthetics in science and science education. Studies in Science Education, 43(1), 38-61.

Girod, M., Rau, C., \& Schepige, A. (2003). Appreciating the beauty of science ideas: teaching for aesthetic understanding. Science Education, 87, 574-587.

Goodnough, K. (2010). The role of action research in transforming teacher identity: modes of belonging and ecological perspectives. Educational Action Research, 18(2), 167-182. 
Gorner, P. (2007). Heidegger's being and time. An introduction. Cambridge: Cambridge University Press.

Granström, H., \& Elmerstad, M. (2016). Det som en gång var. Stockholm: Natur \& Kultur.

Gray, D. \& Sosu, E. (2015). Children, Nature and Well-Being: Young Adults Childhood Experiences of Nature and Links with Mental Well-Being. Poster presentation at the Learning for Sustainability Scotland, Building Connection to Nature Event, Perth.

Gross, S. W. (2002). The neglected Programme of aesthetics. British Journal of Aesthetics, 42(4), $403-414$.

Hansson, L., \& Lindahl, B. (2010). "I have chosen another way of thinking" - Students' relations to science with a focus on worldview. Science \& Education, 19, 895-918.

Hardy, L. (2013). Nature's suit. Husserl's phenomenological philosophy of the physical sciences. Athens: Ohio University Press.

Harvey, C. W. (1989). Husserl's phenomenology and the foundations of natural science. Athens: Ohio University Press.

Heidegger, M. (1962). Being and Time. Oxford UK: Basil Blackwell. [translated by J. Macquarrie and E. Robinson, first published in 1927].

Herman, U. (1992). Knaurs Etymologisches Lexikon. München: Knaur.

Hovardas, T. (2013). A critical reading of ecocentrism and its meta-scientific use of ecology: instrumental versus emancipatory approaches in environmental education and ecology education. Science \& Education, 22, 1467-1483.

Husserl, E. (1940). Grundlegende Untersuchungen zum phänomenologischen Ursprung der Räumlichkeit der Natur. In M. Farber (Ed.), Philosophical essays in memory of Edmund Husserl (pp. 307-325). Cambridge: Harvard University Press.

Husserl, E. (1970). The crisis of the European sciences and transcendental phenomenology. Evanston: Northwestern UP. [First published in 1936].

Jakobson, B., \& Wickman, P.-O. (2008). Art in science class vs science in art class: a study in elementary school. Education \& Didactique, 2(3), 141-157.

Jegstad, K. M., \& Sinnes, A. T. (2015). Chemistry teaching for the future: a model for secondary chemistry education for sustainable development. International Journal of Science Education, 37(4), 655-683.

Jickling, B., \& Wals, A. E. J. (2008). Globalization and environmental education: looking beyond sustainable development. Journal of Curriculum Studies, 40, 1-21.

Jordan, K., \& Kristjánsson, K. (2016). Sustainability, virtue ethics, and the virtue of harmony with nature. Environmental Education Research, advance article. doi:10.1080/13504622.2016.1157681.

Jung, W. (2012). Philosophy of science and education. Science \& Education, 21, 1055-1083.

Kagan, S. (2011). Art and sustainability. Connecting patterns for a culture of complexity. Lüneburg: Leuphana University.

Kagan, S. (2012). Toward global (environ) mental change: transformative art and cultures of sustainability. Publication series ecology, Vol. 20. Berlin: Heinrich-Böll-Stiftung.

Kearns, L.-L. (2015). Subjects of wonder: towards an aesthetics, ethics, and pedagogy of wonder. Journal of Aesthetic Education, 49(1), 98-119.

Kind, P. M., \& Kind, V. (2007). Creativity in science education: perspectives and challenges for developing school science. Studies in Science Education, 43, 1-37.

Larsen, S. C., \& Johnson, J. T. (2012). Toward an open sense of place: phenomenology, affinity, and the question of being. Annals of the Association of American Geographers, 102(3), 632-646.

Lin, H., Hong, Z.-R., Chen, C.-C., \& Chou, C.-H. (2011). The effect of integrating aesthetic understanding in reflective inquiry activities. International Journal of Science Education, 33(9), 1199-1217.

Lindberg, C. A. (2004). The Oxford American Writer's thesaurus. New York: Oxford University Press.

Manni, A. (2015). Känsla, förståelse, och värdering. Elevers meningsskapande i skolaktiviteter om miljö- och hållbarhetsfrågor. PhD-avhandling. Umeå: Institutionen för naturvetenskapernas och matematikens didaktik.

Matthews, M. R. (2009). Teaching the philosophical and worldview components of science. Science \& Education, 18(6), 697-728.

McEwan, I. (2013). Sweet tooth. London: Vintage.

Moran, D. (2000). Introduction to phenomenology. London and New York: Routledge.

Nisbet, E. K., Zelenski, J. M., \& Murphy, S. (2009). The nature relatedness scale. Linking individuals' connection with nature to environmental concern and behavior. Environment and Behavior, 5(41), 715-740.

Omholt, K. (2013). Relational Aesthetics and Education for Sustainable Development. In: Proceedings of the ESERA 2013 Conference. Nicosia, Cyprus. http://www.esera.org/media/eBook_2013/strand\%209/Knut_ Omholt_10mars2014.pdf Accessed 17 October 2016.

Østergaard, E. (2015). Pendulum dialogues and the re-enchantment of the world. In Ø. Varkøy \& F. Pio (Eds.), Philosophy of music education challenged: Heideggerian inspirations (pp. 185-198). Dordrecht: Springer.

Østergaard, E. \& Dahlin, B. (2009). Sound and sensibility. Science teacher students bridging phenomena and concepts. In: Proceedings from 2009 NARST Annual International Conference. April 17-21, 2009, Garden Grove, CA, USA (p. 328). (Full paper on conference CD-ROM). 
Østergaard, E., Dahlin, B., \& Hugo, A. (2008). Doing phenomenology in science education: a research review. Studies in Science Education, 44(2), 93-121.

Pienta, N. J. (2014). Applying science to everyday life. Journal of Chemical Education, 91, 1751-1752.

Pugh, K. J., \& Girod, M. (2007). Science, art, and experience: constructing a science pedagogy from Dewey's aesthetics. Journal of Science Teacher Education, 18, 9-27.

Quay, J. (2013). More than relations between self, others and nature: outdoor education and aesthetic experience. Journal of Adventure Education and Outdoor Learning, 13(2), 142-157.

Root-Bernstein, R. S. (2001). Music, creativity and scientific thinking. Leonardo, 34(1), 63-68.

Root-Bernstein, R. S. (2002). Aesthetic cognition. International Studies in the Philosophy of Science, 16(1), 61-77.

Roth, W.-M. (2015). Enracinement or the earth, the originary ark, does not move: on the phenomenological (historical and ontogenetic) origin of common and scientific sense and the genetic method of teaching (for) understanding. Cultural Studies of Science Education, 10(2), 469-494.

Schroeder, H. W. (2007). Place experience, gestalt, and the human-nature relationship. Journal of Environmental Psychology, 27, 293-309.

Shaw, R. (2013). The implications for science education of Heidegger's philosophy of science. Educational Philosophy and Theory, 45(5), 546-570.

Sinnes, A. \& Eriksen, C. (2015). Education for sustainable development and international student assessment. Global Policy, 1-11. doi: 10.1111/1758-5899.12256.

Sjöström, J., Eilks, I., \& Zuin, V. G. (2016). Towards eco-reflexive science education. A Critical Reflection about Educational Implications of Green Chemistry. Science \& Education, 25, 321-341.

Song, Y. I. K. (2010). Art in nature and school: Nils-Udo. Journal of Aesthetic Education, 44(3), 96-108.

Sterling, S. (2001). Sustainable education. Re-visioning learning and change. Devon: Green Books.

Sterling, S. (2010). Living in the earth. Opinion Essay, Sage Publications, 4(2), 213-218.

Sterling, S. (2014). Separate tracks or real synergy? Achieving a closer relationship between education and SD, post-2015. Opinion Essay, Sage Publications, 8(2), 89-11.

Tal, T., \& Dierking, L. D. (2014). Learning science in everyday life. Journal of Research in Science Teaching, 51(3), 251-259.

Thomas, I. (2009). Critical thinking, transformative learning, sustainable education, and problem-based learning in universities. Journal of Transformative Education, 7, 245-264.

Thomson, I. (2004). Ontology and ethics at the intersection of phenomenology and environmental philosophy. Inquiry, 47, 380-412.

Ullrich, H. (2008). Herausforderungen und Qualitätsfragen eines phänomenologischen Unterrichtes. In J. Schieren (Ed.), Was ist und wie entsteht: Unterrichtsqualität an der Waldorfschule? (pp. 109-125). München: Kopaed.

United Nations (2002). Resolution 57/254. United Nations Decade of Education for Sustainable Development (57/254). http://www.un-documents.net/a57r254.htm Accessed 17 October 2016.

Upadhyay, B. R. (2005). Using students' lived experiences in an urban science classroom: an elementary school Teacher's thinking. Science Education, 90, 94-110.

Vilches, A., \& Gil-Pérez, D. (2013). Creating a sustainable future: some philosophical and educational considerations for chemistry teaching. Science \& Education, 22, 1857-1872.

Voogt, J., \& Roblin, N. P. (2012). A comparative analysis of international frameworks for $21^{\text {st }}$ century competences: implications for national curriculum policies. Journal of Curriculum Studies, 44(3), $299-321$.

Wagenschein, M. (1968). Verstehen lehren: Genetisch-Sokratisch-Exemplarisch. Weinheim: Beltz.

Wagenschein, M. (1990). Kinder auf dem Wege zur Physik. Weinheim and Basel: Beltz Verlag.

Wickman, P.-O. (2006). Aesthetic experience in science education: learning and meaning-making as situated talk and action. Mahwah: Lawrence Erlbaum Ass.

Zahavi, D. (2003). Husserl's phenomenology. Stanford: Standford University Press. 